\title{
Pan-African granulites of central Dronning Maud Land and Mozambique: A comparison within the East-African-Antarctic orogen
}

\author{
A.K. Engvik, ${ }^{1}$ S. Elvevold, ${ }^{2}$ J. Jacobs,${ }^{3}$ E. Tveten, ${ }^{1}$ S. de Azevedo, ${ }^{4}$ and F. Njange ${ }^{5}$ \\ ${ }^{1}$ Geological Survey of Norway, N-7491 Trondheim, Norway (ane.engvik@ngu.no, einar.tveten@ngu.no) \\ ${ }^{2}$ Norwegian Polar Institute, N-9296 Tromsø, Norway (elvevold@npolar.no) \\ ${ }^{3}$ Institute of Geology, University of Bergen, N-5020 Bergen, Norway (joachim.jacobs@geo.uib.no) \\ ${ }^{4}$ National Directorate for Geology, Nampula, Mozambique \\ ${ }^{5}$ National Directorate for Geology, Pemba, Mozambique
}

\begin{abstract}
Granulite-facies metamorphism is extensively reported in Late Neoproterozoic/Early Palaeozoic time during formation of the East-African-Antarctic orogen (EAAO). Metamorphic data acquired from the Pan-African orogen of central Dronning Maud Land (cDML) are compared with data from northern Mozambique. The metamorphic rocks of cDML are characterised by Opx \pm Grt-bearing gneisses and Sil+Kfs-bearing metapelites which indicate medium-P granulite-facies metamorphism. Peak conditions, which are estimated to $800-900^{\circ} \mathrm{C}$ at pressures up to $1.0 \mathrm{GPa}$, were followed by near-isothermal decompression during late Pan-African extension and exhumation. Granulite-facies lithologies are widespread in northern Mozambique, and Grt+Cpx-bearing assemblages show that high-P granulitefacies conditions with PT reaching $1.55 \mathrm{GPa}$ and $900^{\circ} \mathrm{C}$ were reached during the Pan-African orogeny. Garnet is replaced by symplectites of $\mathrm{Pl}+\mathrm{Opx}+\mathrm{Mag}$ indicating isothermal decompression, and the subsequent formation of $\mathrm{Pl}+$ amphibole-coronas suggests cooling into amphibolite facies. It is concluded that high-T metamorphism was pervasive in EAAO in Late Neoproterozoic/Early Paleozoic time, strongly overprinting evidences of earlier metamorphic assemblages.
\end{abstract}

Citatiom: Engvik, A.K., S. Elvevold, J. Jacobs, E.Tveten, S. de Azevedo, and F. Njange (2007), Pan-African granulites of central Dronning Maud Land and Mozambique: A comparison within the East-African-Antarctic orogen: in A Keystone in a Changing World-Online Proceedings of the 10 ${ }^{\text {th }}$ ISAES, edited by A.K. Cooper and C.R. Raymond et al., USGS Open-File Report 2007-1047, Short Research Paper 065, 5 p.; doi:10.3133/of2007-1047.srp065

\section{Introduction}

Granulite-facies rocks are common in most ancient orogenic belts and attest to high-T metamorphic conditions during orogeny (e.g., Harley, 1989). The granulite-facies pressure-temperature domain is subdivided into low-, intermediate- and high-P fields based on the coexistence of orthopyroxene, clinopyroxene and garnet in mafic lithologies (e.g., Spear, 1993). High-P granulites are defined by the mineral assemblage Grt $+\mathrm{Cpx}+\mathrm{Pl} \pm \mathrm{Hbl} \pm \mathrm{Qtz}$ (Pattison, 2003; abbreviations follow Kretz, 1983). Opx coexists with this paragenesis in the intermediate-P field, while Grt disappears in the low$P$ field (Spear, 1993). These three metamorphic fields can be diagnostic of different orogenic or tectonic processes. The P-T path followed by a rock unit in crossing the metamorphic fields is especially diagnostic.

Pan-African (Late Neoproterozoic/Early Paleozoic) granulite-facies metamorphism is extensively reported during the Gondwana assembly (e.g., Harley, 2003). The East-African-Antarctic orogen (EAAO; Fig. 1; e.g. Jacobs and Thomas, 2004) is up to $1000 \mathrm{~km}$ wide and extends for more than $8000 \mathrm{~km}$ along the eastern margin of Africa and into East Antarctica. The EAAO resulted from a multiplate collision of various parts of East- and WestGondwana during Late Neoproterozoic/Early Paleozoic times. This contribution will outline some characteristics of the granulite-facies metamorphism in the EAAO, as derived from studies of the high-grade provinces of northern Mozambique and central Dronning Maud Land (cDML). According to recent plate reconstructions these two areas were juxtaposed in the EAAO (e.g., Jacobs and
Thomas, 2004; Fig. 1). We will compare the metamorphic characteristics of the high-grade metamorphism and the PT-evolution of the two areas, and point out the similarities and differences between the granulites of the two regions. By integrating metamorphic information reported from other parts of the EAAO, it is evident that hot conditions characterised the deep crust in the EAAO. This is in contrast to many other Neoproterozoic and Paleozoic orogens in which eclogites are found.

\section{Granulites of central Dronning Maud Land}

Granulite-facies rocks of central Dronning Maud Land have been documented by Bucher-Nurminen and Ohta (1993), Piazolo and Markl (1999), Engvik and Elvevold (2004), Colombo and Talarico (2004) and Bisnath and Frimmel (2005). Geochronological studies in the area report a Mesoproterozoic crust formation and a Late Neoproterozoic/Early Paleozoic metamorphic event related to the Pan-African orogeny (e.g. Jacobs et al., 1998, Mikhalsky et al., 1997, Paulsson and Austrheim, 2003, Henjes-Kunst, 2004). The Pan-African event in Dronning Maud Land shows a collisional age of 610-550 Ma and an extensional stage at 530-500 Ma (Jacobs et al., 2003).

The metamorphic evolution of gneisses in Orvinfjella $\left(7^{\circ} \mathrm{E}\right)$ is described by Engvik and Elvevold (2004). The peak metamorphism is constrained by the

presence of orthopyroxene in mafic rocks and by the assemblage Grt + Sil +ternary feldspar + Spl + Qtz in metapelites. Grt-bearing leucosomes in metapelites suggest that anatexis occurred through biotite dehydration 
melting which starts at temperatures above $800^{\circ} \mathrm{C}$ (Le Breton and Thompson, 1988). The absence of orthopyroxene in pelitic compositions

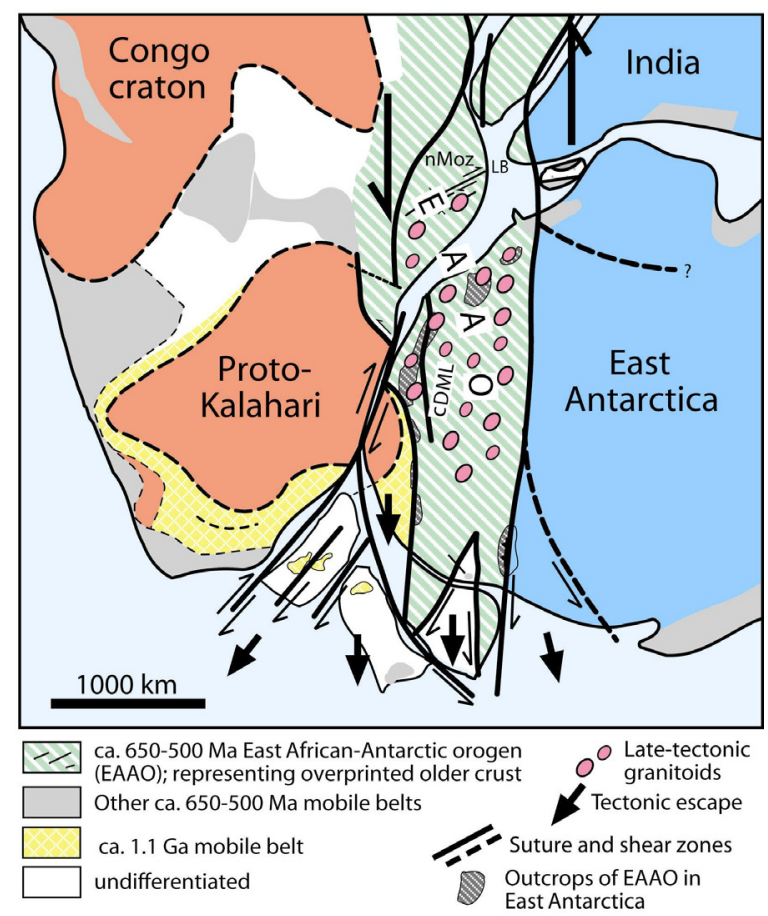

Figure 1. Reconstruction (Jacobs and Thomas, 2004) showing the East-African-Antarctic orogen (EAAO) in late Neoproterozoic-early Paleozoic time. Remark the juxaposition of central Dronning Maud Land (cDML) and northern Mozambique (nMoz). (LB=Lurio belt).

suggests an upper temperature limit of $900-915^{\circ} \mathrm{C}$ (Harley, 1998). The presence of sillimanite as the stable aluminosilicate limits the peak pressure to below $1 \mathrm{GPa}$ at $800^{\circ} \mathrm{C}$. This leads to the interpretation that the gneisses have experienced peak granulite-facies conditions of 800$900^{\circ} \mathrm{C}$ at intermediate pressures. The granulites contain abundant reaction textures recording partial reequilibration to lower pressures. The replacement of garnet and ferritschermakite in mafic rocks by Opx-Pl symplectites suggest decompression while the granulites remained at elevated temperatures (Harley, 1989). In pelitic granulites, Grt + Sil + Spl-bearing assemblages break down to cordierite. Late, nebulous leucosomes in pelitic granulites contain aggregates of cordierite, whereas mafic rocks contain melt patches with euhedral orthopyroxene. The reactions responsible for the partial replacement of Grt-bearing assemblages by cordierite in metapelites are commonly taken as indicative of decompression. The late leucosomes are interpreted to have formed by decompressional melting, which, together with the recorded mineral reactions, indicate that the granulite-facies rocks of Orvinfjella underwent a steep and near-isothermal unloading P-T path (see Fig. 4).

New data on the granulite-facies metamorphism is recorded in Jutulsessen, Gjelsvikfjella $\left(2^{\circ} \mathrm{E}\right)$, by the distribution of Opx-bearing gneisses. A Grt +Opx-bearing granulite (sample AHA307) shows the mineral assemblage garnet $\left(\mathrm{Alm}_{67} \mathrm{Prp}_{5} \mathrm{Grs}_{25} \mathrm{Sps}_{3}\right)$, orthopyroxene $\left(\mathrm{En}_{19} \mathrm{Fs}_{79} \mathrm{Wo}_{2}\right)$, plagioclase $\left(\mathrm{An}_{30}\right)$, quartz and hastingsite (Fig. 2a). Geothermobarometry on this sample yields $P$ about 1.0 GPa (Grt-Opx-Pl-Qtz, Holland and Powell, 1998) and $\mathrm{T}$ of $830^{\circ} \mathrm{C}$ (Grt-Opx, Carswell and Harley, 1990)). Coarse garnet displays resorbed grain boundaries surrounded by Pl coronas (Fig. 2a). The Opx-bearing gneisses are included in amphibole +Bt-bearing migmatites. In addition, a $100 \mathrm{~m}$ wide shear zone contains an Opx-bearing mylonite, where the Opx, occuring as porphyroclasts, are recrystallised and dragged along strings parallel to the foliation (Sample AHA317; Fig. $2 b$ ), illustrating an intense deformation in the granulite facies. In the migmatitic gneisses, Opx is replaced by amphibole and biotite, and well-equilibrated amphibole + Bt-bearing gneisses illustrate retrogression into amphibolite facies.
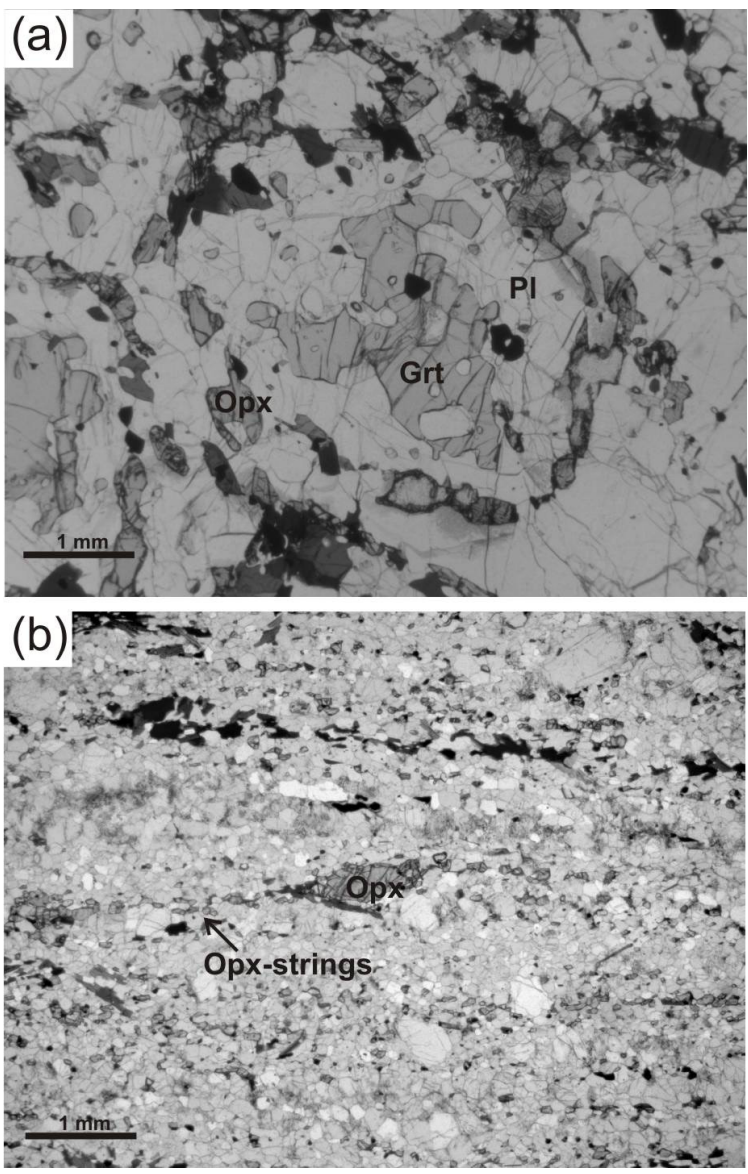

Figure 2. Microphotographs, Jutulsessen, Gjelsvik-fjella in central Dronning Maud Land a) Granulite with preserved $\mathrm{Grt}+\mathrm{Opx}+$ amphibole $+\mathrm{Pl}+\mathrm{qtz}$-assem-blage, sample AHA307. Remark that garnet is surrounded by Plcorona. b) Granulitic mylonite with Opx as porphyroclast, recrystallised and dragged out as strings parallel foliation, sample AHA317. 


\section{Granulites of northern Mozambique}

Northern Mozambique is dominated by Mesoproterozoic gneisses reworked during the Pan-African event (Pinna et al., 1993). The bedrock geology of the area has recently been re-mapped as part of an infrastructure development program (Norconsult Consortium, 2007), which documents widespread occurrence of granulite-facies rocks. The northernmost part is dominated by a nappe stack separated from the southern areas by the prominent $25-30 \mathrm{~km}$ wide Lurio belt. The Lurio belt is a very complex and repeatedly reactivated Pan-African high-strain zone forming a prominent linear ENE-WSW-trending structure in the East Africa (e.g. Viola et al., 2006).
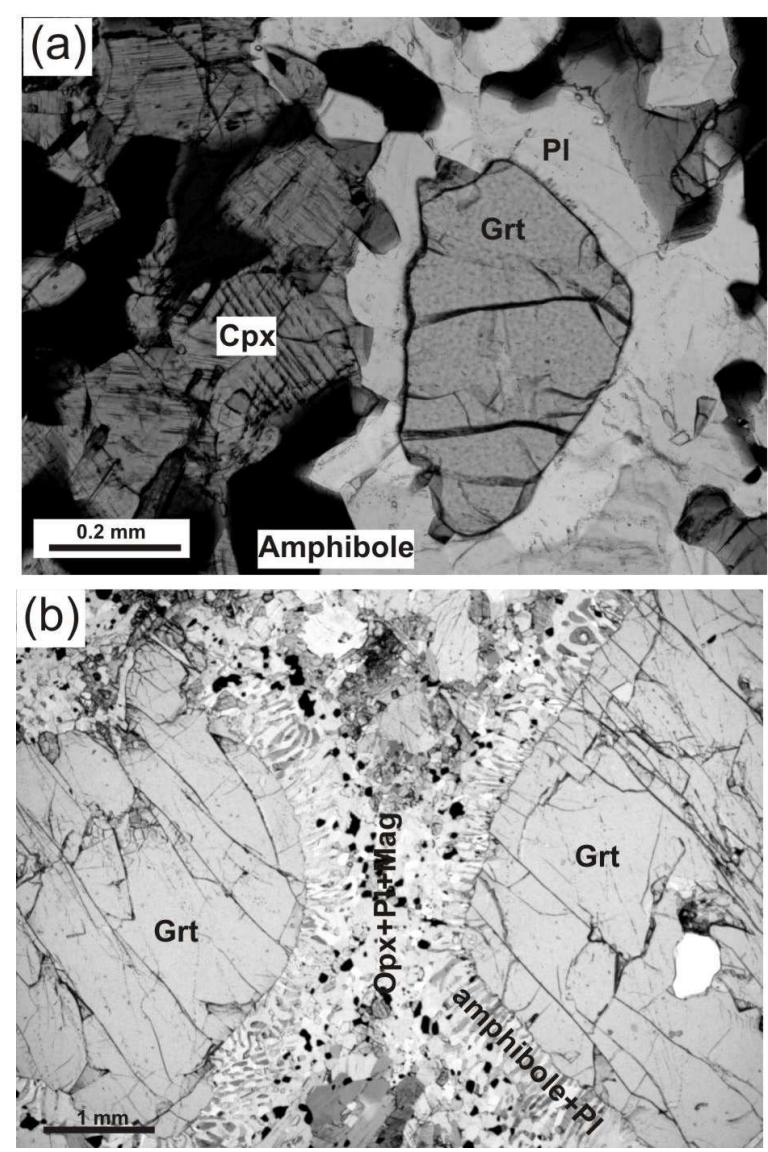

Figure 3. Photomicrographs, granulites of Lurio belt, northern Mozambique. a) Monomineralic Pl-corona surrounding Grt in high-P granulite, sample 40408. b) High-P granulite of the Lurio belt, showing composite corona of $\mathrm{Opx}+\mathrm{Pl}+\mathrm{Mag}$ and amphibole $+\mathrm{Pl}$, respectively, sample 40744.

The Lurio belt is cored by mafic and felsic granulites dated to 580-530 Ma (Norconsult Consortium, 2007). The mafic granulites comprise high-pressure Grt $+\mathrm{Cpx}-$ bearing granulite-facies assemblages. Sample 40744 is composed of Alm-rich garnet, clinopyroxene $\left(\mathrm{En}_{38} \mathrm{Fs}_{12} \mathrm{Wo}_{50}\right)$, plagioclase $\left(\mathrm{An}_{39}\right)$, magnesio-hastingsite and quartz. Garnet porphyroblasts are zoned with a rimward increase in Alm and Sps and decrease in the Grs and Prp components. The core composition is $\mathrm{Alm}_{46} \operatorname{Prp}_{32} \mathrm{Grs}_{21} \mathrm{Sps}_{2}$ and the rim composition is $\mathrm{Alm}_{52} \mathrm{Prp}_{26} \mathrm{Grs}_{19} \mathrm{Sps}_{3}$. The zoning pattern is interpreted as a retrograde diffusion zoning, occurring in the large, up to $5 \mathrm{~mm}$ across, porphyroblasts. The preserved core chemistry in the large porphyroblasts is interpreted to represent peak metamorphic compositions. Geothermbarometry indicates peak metamorphic conditions up to $1.55 \mathrm{GPa}$ and $905^{\circ} \mathrm{C}$ using the geothermobarometers of Holland and Powell (1998) and Ravna (2000) based on the Grt-Cpx-Pl-Qtz and Grt-Cpx assemblages, respectively. Garnet porphyroblasts are commonly surrounded by monomineralic or composite Pl $\pm \mathrm{Opx} \pm$ amphibole $\pm \mathrm{Bt} \pm$ Mag coronas, a typical feature observed in the granulites throughout the crust of northern Mozambique (Fig. 3a). Garnets from mafic granulite of the Lurio belt display composite coronas with $\mathrm{Opx}+\mathrm{Pl}+\mathrm{Mag}$ and $\mathrm{Pl}+$ amphibole symplectite (sample 40744, Fig. 3b). Formation of the $\mathrm{Pl}+\mathrm{Opx}+\mathrm{Mag}$ corona indicates a near-isothermal decomp-ression from high-P granulites facies to lower pressure granulite-facies conditions. The $\mathrm{Pl}$ +amphibole-corona forms by the access to a fluid phase, and indicates cooling into amphibolite-facies conditions.

\section{Discussion and conclusions}

Medium-P granulite-facies metamorphism is documented over a large part of the EAAO in DML, from the western DML (Board et al., 2005), through the central parts (Bucher-Nurminen and Ohta, 1993, Piazolo and Markl, 1999, Engvik and Elvevold, 2004, Colombo and Talarico, 2004, Bisnath and Frimmel, 2005) into the eastern DML (Shiraishi et al., 1997). The metamorphism in cDML reached conditions of $1.0 \mathrm{GPa}, 800-900^{\circ} \mathrm{C}$. The granulite-facies meta-morphism is correlated with the Late Neoproterozoic-Early Palaeozoic Pan-African orogeny (Jacobs et al., 1998, Mikhalsky et al., 1997, Paulsson and Austrheim, 2003, Henjes-Kunst, 2004). The peak metamorphism was followed by decompression and melting, documented by the formation of migmatites and resorption of garnet, a typical feature of the Grt +Opxbearing gneisses of cDML. As described above, the postpeak evolution followed a near-isothermal PT-path (Fig. 4). Evolution of the decompression mineral assemblages are accompanied by extensional shear bands and shear zones evolving from ductile partial melting stage through semiductile towards brittle conditions (Engvik and Elvevold, 2004) and associated with voluminous granitic to charnockitic intrusions (Markl and Piazolo, 1998, Roland 2004, Bucher and Frost, 2005, D'Souza et al., 2006). High-pressure rocks such as eclogites, are not found in Dronning Maud Land. However, preserved remnants of $\mathrm{Ky}+\mathrm{Rt}+\mathrm{Grt}+$ ferri-Ts-assemblages found in Orvinfjella (Engvik and Elvevold, 2004) may represent an early high-P assemblage. In western Dronning Maud Land, recrystallised Cpx $+\mathrm{Pl}$ is interpreted to represent remnants after omphacite (Board et al., 2005), but the 
mineral assemblages are highly overprinted by high-T metamorphism.

Late Neoproterozoic/Early Paleozoic high-grade metamorphism is documented over a large region in Mozambique, Tanzania (Sommer et al., 2003), Malawi (Ring et al., 2002) and Madagascar (Markl et al., 2000). Granulite facies rocks are widespread in northern Mozambique (Norconsult Consortium, 2007). The mineral assemblages and geothermo-barometric results presented in this study from the Lurio belt, show that the granulite-facies metamorphism locally reached high-P conditions during the Pan-African event (Fig. 4).

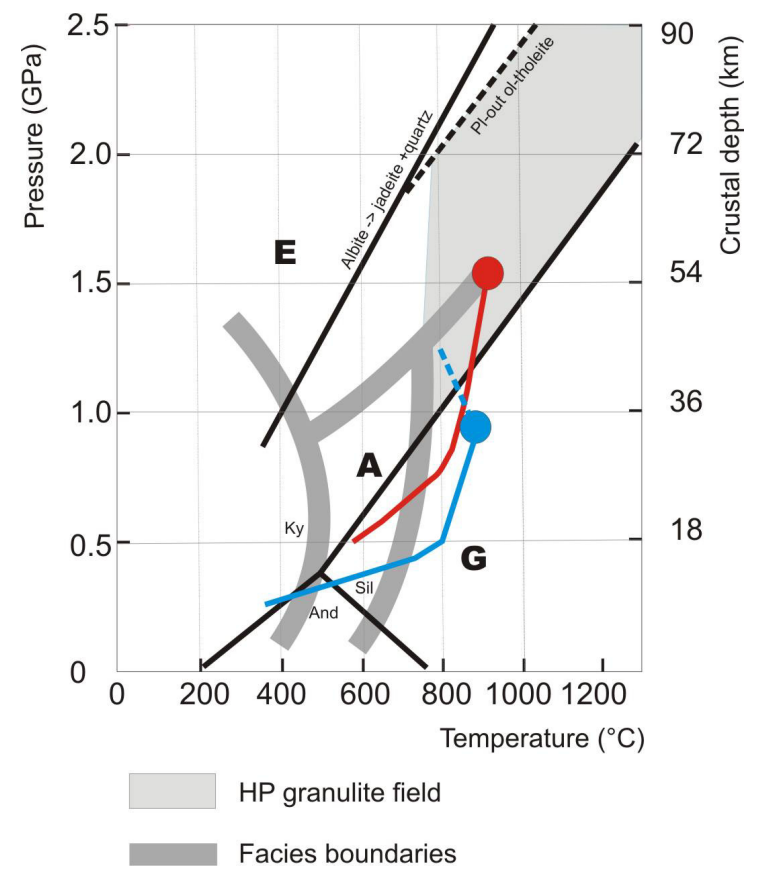

Figure 4. Metamorphic peak (circles) and deduced PTpath from the granulite facies province of cDML (blue colour, after Engvik and Elvevold, 2004) and Lurio belt of northeastern Mozambique (red colour). $\mathrm{E}=$ eclogite facies, $\mathrm{A}=$ amphibolite facies, $\mathrm{G}=$ granulite facies. $\mathrm{HP}$ granulite-facies field as defined by O'Brien and Rötzler (2003).

Textural remnants after omphacite found in Malawi, bordering on Mozambique, illustrate that eclogite-facies conditions were reached during Pan-African time (Ring et al. 2002). The composite corona growth on garnet in the mafic granulites of the Lurio belt, indicate a nearisothermal decompression of the high-P granulites into lower pressure granulites. The peak granulite-facies metamorphism is documented followed by an isothermal or near-isothermal decompression. Similar decompression is documented in Tanzania by resorption and corona growth on garnet, by migmatisation of gneisses and by the formation of cordierite-bearing mineral assemblages (Sommer et al., 2003). The eclogite facies conditions reported in Malawi are strongly overprinted by granulite- facies assemblages, showing an isothermal decompression (Ring et al., 2002).

By comparing the granulite-facies provinces of cDML and northern Mozambique, it is evident that a pervasive medium-P granulite facies metamorphism occurred during formation of the Late Neoproterozoic/Early Paleozoic East-African-Antarctic orogen. The occurrences of high-P granulites are documented in the Lurio belt in northern Mozambique, however, evidences for higher pressures are also shown in cDML (Engvik \& Elvevold, 2004, Board et al., 2005). Both areas record a near-isothermal decompressional evolution after the peak granulite-facies conditions, illustrated by a resorption of garnet and the formation of monomineralic or composite coronas. The metamorphic evolution seems similar in cDML and northern Mozambique, supporting the recent plate reconstructions with juxtaposition of these two areas in EAAO (e.g. Jacobs and Thomas, 2004). However, there are also differences between the granulites recorded in the two areas: In special, extreme enrichment of Fe in garnet and orthopyroxene in the charnockitic lithologies dominating cDML contrasts to the crust exposed in northern Mozambique (Norconsult Consortium, 2007).

The high-T metamorphic conditions are associated with late-orogenic extension in cDML (Jacobs et al. 2003, Engvik \& Elvevold, 2004), and by voluminous lateorogenic granitoid intrusions in both cDML (Roland 2004, Bucher and Frost, 2005, D'Souza et al., 2006) and Mozambique (Norconsult Consortium, 2007). It is concluded that hot conditions characterises the EAAOcrust during Late Neoproterozoic/Early Paleozoic times, and that low-T/high-P rocks such as eclogites are not found. The textural remnants after omphacite interpreted in Malawi (Ring et al., 2002) and Sverdrupfjella of western DML (Board et al., 2005), are strongly overprinted by the high-T metamorphism, which is pervasive in the EAAO of both Antarctica and East Africa.

Acknowledgements This work has partly resulted from the Mineral Resources Management Capacity Building Project, Ministry of Mineral Resources of Mozambique, funded by the Nordic Development Fund and the World Bank, implemented by a team from the Geological Survey of Norway, the British Geological Survey and the National Directorate of Geology of Mozambique. Additional funding from the Norwegian Research Council and the Norwegian Polar Institute is appreciated. We are grateful to B. Bingen and G. Viola for discussions, and to R. Boyd for comments on the manuscript. We thank H. Austrheim and one anonymous referee for helpful reviews which improved the paper.

\section{References}

Bisnath, A., and H.E. Frimmel (2005), Metamorphic evolution of the Maud Belt: P-T-t path for high-grade gneisses in Gjelsvikfjella, Dronning Maud Land, East Antarctica, J Afr Earth Sci, 43, 505-524.

Board, W.S., H.E. Frimmel, and R.A. Armstrong (2005), Pan-African Tectonism in the Western Maud Belt: P-T-t Path for High-grade Gneisses in the H.U. Sverdrupfjella, East Antarctica, J Petrol, 46, 671-699. 
Bucher, K. and B.R. Frost (2005), Fluid Transfer in High-Grade Metamorphic Terrains Intruded by Anorogenic Granites: The Thor Range, Antarctica, J Pet, doi:10.1093/petrology/egi086.

Bucher-Nurminen, K., and Y. Ohta (1993), Granulites and garnetcordierite gneisses from Dronning Maud Land, Antarctica, J Metamorph Geol, 11, 691-703.

Carswell, D.A., and S.L. Harley (1990), Mineral barometry and thermometry: Eclogite facies rocks, edited by D.A. Carswell, pp. 83110, Blackie, Glasgow, London.

Colombo, F., and F. Talarico (2004), Regional Metamorphism in the High-Grade Basement of Central Dronning Maud Land, East Antarctica, Geol. Jb, B96, 7-47.

D'Souza, M.J., A.V.K. Prasad and R. Ravindra (2006). Genesis of Ferropotassic A-Type Granitoid of Mühlig-Hofmannfjella, Central Dronning Maud Land, East Antarctica: Antarctica: Contributions to Global Earth Sciences, edited by D.K. Fütterer, D. Damaske, G. Kleinschmidt, H. Miller and F. Tessensohn, pp. 45-54, Spriner Verlag Berlin Heidelberg.

Engvik, A.K., and S. Elvevold (2004), Pan-African extension and nearisothermal exhumation of a granulite facies terrain, Dronning Maud Land, Antarctica, Geol Mag, 141, 1-12.

Harley, S.L. (1989), The origin of granulites: a metamorphic prospective, Geol Mag, 126, 215-247.

Harley, S.L. (1998), On the occurrence and characterisation of ultrahigh-temperature crustal metamorphism: What Drives Metamorphism and Metamorphic Reactions?, edited by P. J. Treolar and P. J. O'Brien, pp. 81-107, Geol Soc London Spec Publ, 138.

Harley, S.L. (2003), Archaean-Cambrian crustal development in East Antarctica: metamorphic characteristics and tectonic implications: Proterozoic East Gondwana: Supercontinent Assembly and Breakup, edited by M. Yoshida, B. F. Windley and S. Dasgupta, pp. 203-230, Geol Soc London Spec Publ, 206.

Henjes-Kunst, F. (2004), Further Evidence for Pan-African Polyphase Magmatism and Metamorphism in Central Dronning Maud Land, East Antarctica, from Rocks at Schirmakeroasse: A Geochronological Study, Geol Jb, B96, 255-292.

Holland, T.J.B., and R. Powell (1998), An internally consistent thermodynamic data set for phases of petrological interest, $\mathrm{J}$ Metamorph Geol, 16, 309-343.

Jacobs, J., W. Bauer and C.M. Fanning (2003), Late Neoproterozoic/Early Palaeozoic events in central Dronning Maud Land and significance for the southern extension of the East African Orogen into East Antarctica, Precambrian Res, 126, 27-53.

Jacobs, J., and R.J. Thomas (2004), Himalayan-type indenter-escape tectonics model for the southern part of the late Neoproterozoic-early Paleozoic East-African-Antarctic Orogen, Geology 32, 721-724.

Jacobs, J., C.M. Fanning, F. Henjes-Kunst, M. Olesch and H.-J. Paech (1998), Continuation of the Mozambique Belt into East Antarctica: Grenville-Age Metamorphism and Polyphase Pan-African HighGrade Events in Central Dronning Maud Land, J Geol, 106, 385-406.

Kretz, R. (1983), Symbols for rock-forming minerals, Amer Mineral, $68,277-279$

Le Breton N., and A.B. Thompson, 1988, Fluid-absent (dehydration) melting of biotite in metapelites in the early stage of crustal anatexis, Contrib Min Pet, 99, 226-237.

Markl, G., J. Bäuerle and D. Grujic (2000), Metamorphic evolution of Pan-African granulite facies metapelites from Southern Madagascar, Precambrian Res, 102, 47-68.

Markl, G. and S. Piazolo (1998), Halogen-bearing minerals in syenites and high-grade marbles of Dronning Maud Land, Antarctica: monitors of fluid compositional changes during late-magmatic fluidrock interactions processes. Contrib Min Pet, 132, 246-268.

Mikhalsky, E.V., E.V. Beliatsky, E.V. Savva, H.-U. Wetzel, L.V. Federov, T.H. Weiser and K. Hahne (1997), Reconnaissance Geochronologic Data on Polymetamorphic and Igneous Rocks of the Humboldt Mountains, Central Queen Maud Land, East Antarctica: Geological Evolution and Processes: The Antarctic Region Siena, edited by C.A. Ricci, pp. 45-53, Terra Antarctica Publications.

Norconsult Consortium (2007), Mineral resources management capacity building project, Republic of Mozambique; Component 2: Geological infrastructure development project, Geological Mapping Lot 1; Sheet explanation: 32 sheets; scale: 1/250000, p. 778 pp. + annexes. Credit No. NDF335, Report No. B6.f., National Directorate of Geology, Republic of Mozambique.

O'Brien, P. J., and J. Rötzler (2003), High-pressure granulites: formation, recovery of peak conditions and implications for tectonics, J Metamorph Geol, 21, 3-20.

Pattison, D.R.M. (2003), Petrogenetic significance of orthopyroxenefree garnet + clinopyroxene + plagioclase \pm quartz-bearing metabasites with respect to the amphibolite and granulite facies, J Metamorph Geol, 21, 21-34.

Paulsson, O., and H. Austrheim (2003), A geochronological and geochemical study of rocks from Gjelsvikfjella, Dronning Maud Land, Antarctica - implications for Mesoproterozoic correlations and assembly of Gondwana, Precambrian Res, 125, 113-138.

Piazolo, S., and G. Markl (1999), Humite- and scapolite-bearing assemblages in marble and calcsilicates of Dronning Maud Land, Antarctica: new data for Gondwana reconstructions, J Metamorph Geol, 17, 91-107.

Pinna, P., G. Jourde, J.Y. Calvez, J.P. Mroz and J.M. Marques (1993), The Mozambique Belt in northern Mozambique; Neoproterozoic (1100-850 Ma) crustal growth and tectogenesis, and superimposed Pan-African (800-550 Ma) tectonism, Precambrian Res, 62, 1-59.

Ravna, E.J.K. (2000), The garnet-clinopyroxene geothermometer: an updated calibration, J Metamorph Geol, 18, 211-219.

Ring, U., A. Kröner, R. Buchwaldt, T. Toulkeridis and P.W. Layer (2002), Shear-zone patterns and eclogite-facies metamorphism in the Mozambique belt of northern Malawi, east-central Africa: implications for the assembly of Gondwana, Precambrian Res, 116, 19-56.

Roland, N.W. (2004), Pan-African Granite-Charnockite Magmatism in Central Dronning Maud Land, East Antarctica: Petrography, Geochemistry and Plate Tectonic Implications, Geol Jb, B96, 187232.

Shiraishi, K., C.M. Fanning, R. Armstrong and Y. Motoyoshi (1999), New evidence for polymetamorphic events in the Sør Rondane Mountains, East Antarctica, Programme and Abstracts of the $8^{\text {th }}$ International Symposium of Antarctic Earth Sciences, Wellington, 280.

Sommer, H., A. Kröner, C. Hauzenberger, S. Muhongo and M.T.D. Wingate (2003), Metamorphic petrology and zircon geochronology of high-grade rocks from the central Mozambique Belt of Tanzania: crustal recycling of Archean and Palaeoproterozoic material during the Pan-African orogeny, J Metamorph Geol, 21, 915-934.

Spear, F.S., (1993) Metamorphic Phase Equilibria and PressureTemperature-Time Paths, Mineral Soc Amer, Washington.

Viola, G., I. Henderson, B. Bingen and P. Feito (2006). A new tectonic framework for northern Mozambique. CAG21, Maputo, Mozambique, Abstract volume pp. 168-169. 